\title{
Engajamento e sacrifício \\ o pensamento estético de Mário de Andrade
}

\author{
Pedro Fragelli ${ }^{1}$
}

\section{Resumo}

Mário de Andrade concebeu e organizou a totalidade de sua obra como uma forma de práxis social. Por isso mesmo, realizou uma reflexão profunda e dramática sobre a difícil relação entre arte e sociedade no Brasil. Sobretudo a partir de 1930, procura desenvolver um pensamento estético nucleado pela ideia da função social da arte, tendo em vista encontrar e promover formas de intervenção política por meio da cultura. Mário, entretanto, não superou, no plano teórico, a ideia de que os elementos estético e político da obra de arte se contradizem. Este artigo procura expor o movimento e as contradições do pensamento estético marioandradino, assim como da solução que o escritor encontra para seus torturantes dilemas - o sacrifício. As reflexões de Mário são aqui estudadas em sua relação com a matéria histórica, em especial com o processo de desarticulação, operado pelo Estado nas décadas de 1920 e 1930, do incipiente movimento operário brasileiro, que começava a organizar a luta de classes no país ${ }^{2}$.

\section{Palavras-chave}

Mário de Andrade, estética, engajamento político, sacrifício.

Recebido em 08 de Março de 2013

Aprovado em 23 de Agosto de 2013

FRAGELLI, Pedro. Engajamento e sacrificio: o pensamento estético de Mário de Andrade. Revista do Instituto de Estudos Brasileiros, Brasil, n. 57, p. 83-110, 2013. D0I: http://dx.doi.org/10.11606/issn.2316-901X.v0i57p83-110

I Universidade de Paris III - Sorbonne Nouvelle (Paris, França).

2 Este artigo é o desenvolvimento de parte de um trabalho mais amplo sobre a presença e o sentido do complexo sacrificial na obra de Mário de Andrade. Pedro Coelho Fragelli. A Paixão segundo Mário de Andrade. Tese (Doutorado em Literatura Brasileira) - Faculdade de Filosofia, Letras e Ciências Humanas, Universidade de São Paulo, 2010. Orientador: Prof. Dr. José Antonio Pasta Jr. 


\title{
Engagement and Sacrifice \\ the Aesthetic Thought of Mário de Andrade
}

\section{Pedro Fragelli}

\begin{abstract}
Mário de Andrade conceived and organized his whole work as a means of social praxis. He therefore developed a profound and dramatic thought about the difficult relation between art and society in Brazil. Especially from 1930, when the Brazilian ideological life became strongly politicized, Mário seeks to develop an aesthetic thought centered on the idea of art's social function, in order to promote forms of political intervention through culture. Mário however could not overcome in theory the idea that the aesthetic and the political elements of artworks contradict one another. This article intends to expose the movement and paradoxes of the writer's aesthetic thought, as well as those of the solution that Mário finds for his torturous dilemmas - that is, sacrifice. Mário's ideas are studied here in their relations with history, especially with the process - carried out by the State during the 1920s and the 1930s - of dismantling the incipient Brazilian labour movement, which started to organize class struggle in the country.
\end{abstract}

Keywords

Mário de Andrade, aesthetics, political engagement, sacrifice. 


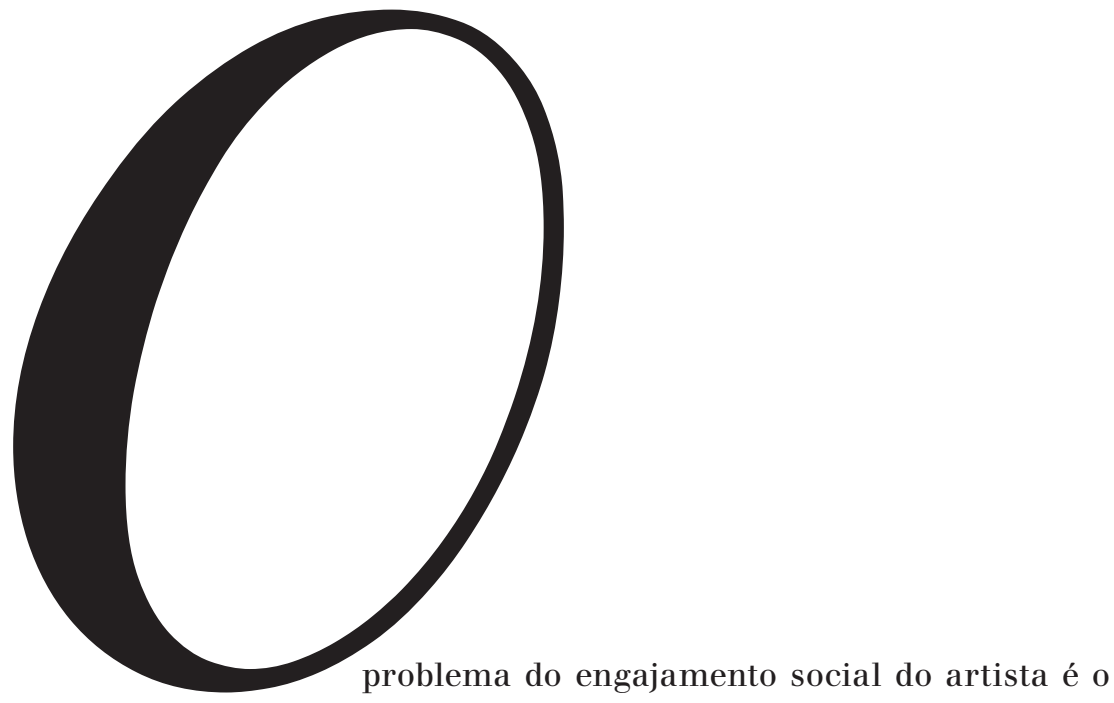

fio vermelho que atravessa - e unifica - a variadíssima e contraditória obra de Mário de Andrade. A esse fio, entretanto, de ponta a ponta, outro se entretece e faz contraste: a noção de sacrifício. Em sua penúltima entrevista, publicada em janeiro de 1944 em uma revista carioca, Mário declara:

Sempre fui contra a arte desinteressada. Para mim, a arte tem de servir. Posso dizer que desde o meu primeiro livro faço arte interessada. [...] A arte tem de servir. Venho dizendo isso há muitos anos. É certo que tenho cometido muitos erros na minha vida. Mas com a minha "arte interessada", eu sei que não errei. Sempre considerei o problema máximo dos intelectuais brasileiros a procura de um instrumento de trabalho que os aproximasse do povo. Esta noção proletária da arte, da qual nunca me afastei, foi que me levou, desde o início, às pesquisas de uma maneira de exprimir-me em brasileiro. [...] Às vezes, com sacrifício da própria obra de arte. [...] A responsabilidade do artista para com o seu público [...] esta é que é difícil, esta é que impõe mil sacrifícios (de que não é o menos doloroso, reconheço, o sacrifício de sua própria arte), esta responsabilidade é que impõe o exercício do seu não conformismo. [...] O artista não só deve, mas tem que desistir de si mesmo. ${ }^{3}$

Na mesma linha, n’O banquete, série inacabada de crônicas escritas por Mário de Andrade no último ano de sua vida, o compositor Janjão,

3 “Acusa Mário de Andrade: ‘Todos são responsáveis!'”. Entrevista para Francisco de Assis Barbosa. Diretrizes, n. 184, p. 1, 6 jan. 1944. In: LOPEZ, Telê Porto Ancona (org.). Mário de Andrade: entrevistas e depoimentos. São Paulo: T. A. Queiroz, 1983. p. 104-108. 
personagem principal desses textos - e que em grande medida expressa as ideias angustiadas de Mário sobre a arte de seu tempo -, afirma com fervor:

O princípio mesmo da arte deste nosso tempo é o princípio de revolução. [...] O humano, o utilitariamente humano é o que eu pretendo. Não o "humano" acomodativo dos artistas que tudo convertem a valores gerais, os "valores eternos", mas o combativo e transitório. Mesmo o transitório, mesmo a arte de circunstância, morta cinco anos depois. Que valor mais terá meu Esquerzo Antifachista, depois que Mussolini virou pó de traque? Nenhum. Nem me interessa que tenha mais algum. [...] Nós temos que adotar os princípios da arte-ação. Sacrificar as nossas liberdades, as nossas veleidades e pretensõezinhas pessoais; e colocar como cânone absoluto da nossa estética, o princípio de utilidade. o princípio de utilidade. ${ }^{4}$

Mário concebeu e organizou toda a sua atividade intelectual como uma forma de práxis. Não foi somente ele o escritor brasileiro que realizou a reflexão mais ampla sobre as relações entre cultura e política no Brasil, mas também o que se dedicou de maneira mais consciente, obstinada, generosa e dramática a promover a função social da arte no país.

A missão não era fácil. Como se sabe, a cultura erudita no Brasil, baseada em sua maior parte na imitação de modelos europeus, constituía um privilégio das elites, cujo desejo mais dileto, no campo das ideias, era sentir-se parte da burguesia europeia, o que supunha manter distância absoluta das formas artísticas populares locais. Por sua vez, a cultura popular brasileira jazia esparsa, fragmentada em manifestações isoladas, no vasto território do país, tendendo a desaparecer à medida que o capitalismo avançava.

Apesar do cenário desfavorável e desanimador - ou justamente em função dele -, Mário idealizou desde o início dos anos 1920 um ambicioso projeto pessoal e cultural, tendo em vista integrar a totalidade da cultura brasileira por meio da articulação da produção artística com as forças sociais do país. Para realizar esse grandioso programa de "ida ao povo", Mário militou em quase todos os campos da cultura: escreveu poesia, romances, contos, ensaios críticos sobre literatura, música, pintura e escultura, estudos de folclore brasileiro, libretos de ópera e artigos de jornal, além de uma vastíssima correspondência, em que ressalta o desejo de estimular a natureza coletiva do trabalho intelectual no Brasil; realizou duas longas viagens etnológicas ao Norte do país, incluindo a

4. ANDRADE, Mário de. O banquete. São Paulo: Duas Cidades, 1989. p. 68, 130. 
floresta amazônica, para registrar centenas de danças, lendas, melodias e rituais populares tradicionais; como diretor do Departamento de Cultura de São Paulo, entre 1934 e 1936, desenvolveu programas de democratização cultural na cidade, até que o Estado varguista o levasse a demitir-se; elaborou o anteprojeto para a criação do Serviço do Patrimônio Histórico Nacional; e foi professor durante toda a vida. Em suma, Mário organizou sua vida e sua obra tendo em vista a realização de uma intervenção profunda e decisiva na história da cultura brasileira, de modo a fundamentar a produção artística nacional nas matrizes da cultura popular do país.

Inicialmente, durante os chamados "anos heroicos" do modernismo brasileiro, ao longo da década de 1920, Mário limitou o alcance dessa intervenção ao campo da cultura, como se a democracia cultural pudesse ser promovida sem a promoção da cidadania ${ }^{5}$. A partir de 1930 , o fim da utopia do café - ou seja, a crença de que a economia cafeeira levaria o Brasil à modernidade sem produzir os recalques e alienações burguesas $^{6}$ - e a decepção com o sentido conservador da Revolução de 1930 levaram os principais intelectuais brasileiros, na expressão de Antonio Candido, a tomarem consciência do subdesenvolvimento do país ${ }^{7}$. Mário, de sua parte, torna-se cada vez mais consciente de que a formação de uma cultura socialmente integrada supõe a formação de uma sociedade politicamente integrada, portanto implica não apenas a revolução estética, mas também, e sobretudo, a revolução política. Assim, durante os quinze últimos anos de sua vida, entre 1930 e 1945, Mário passa a concentrar sua atividade na concepção e na produção de uma arte militante, voltada para a transformação sociopolítica do Brasil. Esse processo, que inclui uma aproximação com o comunismo, consuma-se na elaboração da ópera Café, em que se encena uma grandiosa revolução popular, a revolução que o movimento de 1930 ficara devendo.

Contudo, embora tenha sido o artista de seu tempo que se empenhou de forma mais duradoura, cuidadosa e apaixonada para relacionar cultura e política no Brasil, Mário jamais superou a ideia de que a

5 O próprio Mário, na alta maturidade, reconhece o caráter que ele chama de "aristocrático" do modernismo de 1920: "Apesar da nossa atualidade, da nossa nacionalidade, da nossa universalidade, uma coisa não ajudamos verdadeiramente, duma coisa não participamos: o melhoramento político-social do homem". ANDRADE, Mário de. O Movimento Modernista [1942]. In: Aspectos da literatura brasileira. Belo Horizonte: Itatiaia, 2002. p. 280.

6 Ver SCHWARZ, Roberto. A carroça, o bonde e o poeta modernista. In: Que horas são?. São Paulo: Companhia das Letras, 1997. p. 11-28.

7 CANDIDO, Antonio. Literatura e subdesenvolvimento. In: . A educação pela noite \& outros ensaios. São Paulo: Ática, 200o. p. 14 ,o. 
produção artística engajada supõe, em maior ou menor medida, o sacrifício da qualidade estética da obra de arte.

A presença dessa contradição na obra de Mário remonta ao livro de estreia do escritor - publicado em 1917 -, que pertence a uma espécie de pré-história da produção literária marioandradina, mas que a conjunção de engajamento artístico e gesto sacrificial modela, já, de maneira fundamental e bastante expressiva. Trata-se de um conjunto de poemas pacifistas sobre a Primeira Guerra Mundial, reunidos sob o título, sugestivo para nós, de Há uma gota de sangue em cada poema. Uma análise detida desse livro, que não cabe aqui, revelaria que ele tem na liturgia católica - em especial, na missa - seu modelo compositivo principal; em outras palavras, mostraria que Há uma gota de sangue se organiza, em sua estrutura e em suas imagens, como um rito sacrificial de natureza eucarística, por meio do qual o eu- lírico procura realizar uma metódica imolação de si mesmo com o objetivo de pacificar a Europa por meio da poesia (não por acaso, na ocasião da primeira edição da obra, Mário fez questão de que sobre cada poema do livro fosse impressa uma gota vermelha - muitas vezes na forma de um bico de pena, como se a poesia tivesse sido escrita com o próprio sangue do autor). Sobre a publicação desse livro, Mário escreveu em carta de 1935:

Fazia já muitos anos que eu escrevia versos e contos, só contos e versos, quando em 1917, violentado pela Guerra, desesperado por ver os homens inimigos entre si, escrevi de repente uma série de versos de intenção manifestamente pacifista, e publiquei-os, Há uma gota de sangue em cada poema. Eram versos que, no tempo, eu não achava ruins, hoje acho. Porém, mesmo então, eu sabia, conscientemente sabia que na minha coleção vastíssima de inéditos, estavam sonetos, principalmente sonetos, muito melhores que aqueles versos. Esses sonetos, os versos inéditos, eu fizera sempre dentro do destino do artista, buscando livremente a perfeição. Mas aqueles, os do livro publicado, clamavam o horror da guerra, da inimizade entre os homens, do saque de Lovaina. ${ }^{8}$

8 Carta de Mário de Andrade a Sousa da Silveira, 15 de fevereiro de 1935. In: FERNANDES, Lygia. Mário de Andrade escreve cartas a Alceu, Meyer e outros. Rio de Janeiro: Editora do Autor, 1968. p. 147. O dilema que se impõe ao escritor no momento da publicação de suas obras é discutido por Mário em três artigos de 1931, significativamente intitulados "O castigo de ser", nos quais o autor analisa a necessidade de 0 artista escolher entre publicar as obras que sua consciência pessoal considera belas e aquelas que sua consciência social considera úteis: "É de todo inútil o artista publicar apenas obras que ele julgue conscientemente ótimas. Se ele se satisfaz com essa lealdade de consciência pessoal é porque é um individualista 
Como se terá notado, Mário pressupõe uma antinomia entre o valor político e o valor estético da obra de arte, sugerindo que a destinação prática e coletiva da produção artística constrange a liberdade criadora, condição essencial da excelência das obras. Em outras palavras, de acordo com o pensamento marioandradino, o engajamento político da obra de arte restringe o desenvolvimento integral das potencialidades históricas do material artístico e dos procedimentos composicionais, desenvolvimento indispensável, ainda segundo Mário, para a realização da qualidade propriamente estética de uma obra de arte, isto é, para a criação da beleza:

Só no Brasil eu penso e por ele tudo sacrifiquei. A língua que escrevo, as ilusões que prezo, os modernismos que faço são pro Brasil. [...] Estraçalho a minha obra. Escrevo língua imbecil, penso ingênuo, só pra chamar a atenção dos mais fortes do que eu pra este monstro mole e indeciso que ainda é o Brasil. ${ }^{9}$

Quando considerado em perspectiva teórica, de fato, o belo costuma ser entendido por Mário de Andrade como o elemento puramente "hedonístico" da obra de arte, como o fator que a distancia da práxis. Nessa linha, em uma série de crônicas dedicadas ao assunto, publicadas em junho de 1929 no Diário Nacional, o escritor associa a beleza artística ao "desinteresse" - isto é, à ausência de engajamento social - da obra de arte:

Desinteresse e Beleza não são elementos desrelacionados e esta é filha daquele. A gente se servindo da Beleza pra criar a obrade-arte e atingir a Arte enfim, não faz mais do que empregar um elemento que fortifique a função de desinteresse que a Arte tem.

medonho, um vaidoso de si; consciente ou inconscientemente é um vaidoso que não sabe ter o verdadeiro orgulho capaz de sacrifícios, é um torre-de-marfim, é um egoísta, um egocêntrico, um ser dessocializado. [...] O ideal seria então o artista só publicar aquilo que a sua consciência social reputa bom [no sentido de útil] e a sua consciência pessoal reputa belo? É um engano. Porque ambas estas duas consciências são contraditórias. Quem tem a segunda é um egoísta, se indiferentiza no individualismo e não pode obter a primeira. E esta primeira despreza a segunda e a repudia. A lealdade pra com a consciência social é a única que nobilita o artista e o justifica satisfatoriamente em sua humanidade". ANDRADE, Mário de. O castigo de ser - II. In: . Táxi e crônicas no Diário Nacional. Belo Horizonte: Itatiaia, 2005. p. 370 (grifos meus).

9 ANDRADE, Carlos Drummond de. A lição do amigo: cartas de Mário de Andrade a Carlos Drummond de Andrade. Rio de Janeiro: José Olympio, 1982. p. 6. 
A beleza artística não é senão mais um meio com que a gente consegue tornar a obra-de-arte e a Arte desinteressadas. ${ }^{10}$

Concebida como perfeição formal, a noção de beleza artística se projeta, nas reflexões estéticas de Mário, no campo do absenteísmo: “O destino real dos grandes artistas é aquela permanência após a morte, aquela atividade certamente mais fecunda e menos propriamente humana que divina, de criar o descanso, o prazer, a evasão deste mundo que a Beleza dá"11.

Se, por um lado, a orientação política da obra de arte limita a produção da "beleza", ou seja, restringe o desenvolvimento das possibilidades históricas do material artístico, a realização desse potencial estético tende a diminuir, por outro, a força política da obra de arte. Assim, a partir dos anos 1930, quando sua obra sofre uma inflexão para a política, Mário de Andrade, que fora o principal líder vanguardista nos anos febris da "revolução" modernista no Brasil, passará a criticar as vanguardas, acusando-as, não sem alguma razão, de serem formalistas, de praticarem um esteticismo individualista, de terem cortado, em síntese, os vínculos da arte com o povo:

O distanciamento entre a arte contemporânea e as massas populares atingiu tal e tão abstruso exaspero que é muito difícil estabelecer que função artística podem exercer as criações exacerbadamente "hedonísticas" de um Léger na pintura, de um Schoenberg na música, como de um Joyce na literatura. ${ }^{12}$

Conforme radicaliza o engajamento sociopolítico de sua atividade intelectual, Mário de Andrade assume em relação às vanguardas posições que lembram a hostilidade que Lukács desenvolveria contra o modernismo europeu na mesma época. Cada vez mais, verá nos procedimentos vanguardistas a expressão de uma burguesia decadente. Em um de seus últimos textos, o ensaio sobre Shostakovich, Mário celebra na obra do compositor soviético o "tonalismo decidido", "a volta a princípios construtivos tradicionais dos séculos XVIII e XIX”, como a sonata e a sinfonia, e “o repúdio ao esteticismo individualista deliquescente

10 ANDRADE, Mário de. Desinteresse - II. In: . Táxi e crônicas no Diário Nacional, op. cit., p. 97 .

11 Carta de Mário de Andrade a Sousa da Silveira, 15 de fevereiro de 1935. In: FERNANDES, Lygia. Mário de Andrade escreve cartas a Alceu, Meyer e outros, op. cit., p. 149.

12 ANDRADE, Mário de. Distanciamentos e aproximações [1942]. In: . Música, doce música. Belo Horizonte: Itatiaia, 2006. p. 351-355. 
da música burguesa contemporânea”, assim como Lukács defenderia o resgate do romance realista clássico em Thomas Mann, contra o experimentalismo literário de Proust ou Kafka, por exemplo ${ }^{13}$. No campo da poesia, a técnica do verso livre, escandalosamente propugnada por Mário nos primeiros anos da década de 1920 - sobretudo no "Prefácio interessantíssimo", de Pauliceia desvairada (1922), e no ensaio "A escrava que não é Isaura" (1924) -, passa a ser vista pelo escritor como "uma vitória do individualismo", portanto, como antissocial, em oposição ao verso medido, de alto "poder socializante":

A rima e o metro têm razão, têm motivo imemorial coletivo. [...] Pra obter uma eficiência mais larga, mais geral, de combate, é preciso abandonar o individualismo do verso-livre, e usar do coletivismo marcial ou cancioneiro dos metros e suas consequências rítmicas em que a consonância se inclua. ${ }^{14}$

Apesar dos esforços desmedidos que realizou para dialetizar a relação entre estética e política, Mário não conseguiu formular, portanto, uma reflexão propriamente dialética sobre essa relação, na qual intenção política revolucionária e experimentação artística radical aparecessem mediadas uma pela outra. Na maior parte de sua obra teórica, Mário não superou a dicotomia a que Benjamin se referiu como sendo característica de uma reflexão não dialética sobre o tema: "por um lado, devemos exigir que o autor siga a tendência política correta, e por outro lado temos o direito de exigir que sua produção seja de boa qualidade" ${ }^{15}$.

13 Andrade, Mário de. Introdução a Shostakovich [1945]. In: COLI, Jorge. Música final: Mário de Andrade e sua coluna jornalística Mundo Musical. Campinas: Editora da Unicamp, 1998. p. 397. Para a polêmica de Lukács contra as vanguardas, ver seu ensaio “Trata-se do realismo!". In: MACHADO, Carlos Eduardo Jordão. Um capítulo da história da modernidade estética: debate sobre o expressionismo. São Paulo: Editora Unesp, 1998. p. 195-231. Em sentido análogo, no conhecido ensaio "Narrar ou descrever", Lukács defende a ideia de que um ramo da prosa moderna, seu ramo propriamente moderno, que se inicia em Flaubert e culmina em Joyce e John dos Passos, constitui uma manifestação artística da decadência burguesa. Ver LUKÁCS, Georg. Ensaios sobre literatura. Rio de Janeiro: Civilização Brasileira, 1968. p. 47-99.

14 Carta de Mário de Andrade a Guilherme Figueiredo, 6 de agosto de 1944. ANDRADE, Mário de. A lição do guru (cartas a Guilherme Figueiredo, 1937-1945). Rio de Janeiro: Civilização Brasileira, 1989, p. 107. Ver também: Idem. A poesia em 1930 [1931]. In: Aspectos da literatura brasileira, op. cit., p. 38-40.

15 BENJAMIN, Walter. O autor como produtor. In: - Magia e técnica, arte e política: ensaios sobre literatura e história. Obras escolhidas 1. São Paulo: Brasiliense, 2008. p. 121. 
É bem verdade que intuiu uma mediação que operasse, no campo da arte, uma síntese entre engajamento social e qualidade estética. Conforme notou João Luiz Lafetá, Mário de Andrade esboça, em alguns de seus melhores textos da maturidade, a possibilidade de superação da antinomia por meio da noção de técnica ${ }^{16}$. Assim, no ensaio "O artista e o artesão", de 1938, o conceito de “técnica pessoal” permite a Mário conceber uma articulação dialética entre o artista e a cultura, entre o indivíduo e a sociedade, na medida em que o exercício dessa técnica realiza uma síntese - um "justo equilíbrio", diz o escritor - entre artesanato e criatividade, isto é, entre expressão subjetiva e tradição coletiva. Desenvolvendo-se concretamente no embate do artista, munido de conhecimento técnico prévio, com seu outro, o material, que impõe limites à criação e exige soluções estéticas novas, específicas, a "técnica pessoal” proporciona, segundo Mário, “a aquisição de uma severa consciência artística", que é sobretudo uma consciência "moral"17. Em outros termos, a categoria do trabalho - em sentido próximo ao que Hegel confere ao conceito na Fenomelogia do Espírito - aparece para Mário como a mediação entre estética e política ${ }^{18}$. Três anos mais tarde, no célebre ensaio "A elegia de abril", Mário aprofunda essa relação, dispondo-a sob perspectiva ainda mais engajada: "Imagino que uma verdadeira consciência técnica profissional poderá fazer com que nos condicionemos ao nosso tempo e o superemos. [...] Se o intelectual for um verdadeiro técnico da sua inteligência, ele não será jamais um conformista" ${ }^{19}$.

Nesses momentos, o pensamento estético de Mário de Andrade aproxima-se da ideia de que, nas palavras de Benjamin, "a tendência política correta de uma obra inclui sua qualidade literária", ou ainda, agora nos termos de Adorno, de que "não há obra de arte cuja consciência social é verdadeira que não se prova em termos de qualidade estética" ${ }^{20}$. Nenhum outro escritor modernista brasileiro realizou uma reflexão tão avançada sobre as relações entre arte e sociedade. Essa concepção, entretanto, é

16 LAFETÁ, João Luiz. 193o: a crítica e o modernismo. São Paulo: Duas Cidades/Editora 34, 2000. p. 211.

17 ANDRADE, Mário de. O artista e o artesão [1938]. In: O baile das quatro artes. São Paulo: Livraria Martins Editora, 1975. p. 13-33.

18 Na mais conhecida passagem da Fenomenologia, a "dialética do senhor e do escravo", o trabalho aparece como a atividade formadora da consciência de si livre, mediante a relação da consciência com a natureza. HEGEL, G. W. F. Fenomenologia do Espírito. Petrópolis: Vozes, 2002. p. 142-151.

19 ANDRADE. Mário de. A elegia de abril [1941], In: Aspectos da literatura brasileira, op. cit., p. 216.

20 BENJAMIN, Walter, op. cit., p. 122-123 (grifo meu); ADORNO, Theodor W. Teoria estética. Lisboa: Edições 70, 200o. p. 349. 
apenas vagamente delineada pelo autor de Macunaíma, que em seus últimos textos tende a retornar ao esquema não dialético - como no ensaio sobre Shostakovich, já citado, em que o atonalismo e a música engajada são considerados incompatíveis, ou em uma passagem sobre Lasar Segall, em que Mário repõe a perspectiva antidialética no movimento mesmo pelo qual procura dialetizar estética e política, de modo que o trecho se torna particularmente expressivo da dificuldade que o escritor encontrava para superar o impasse teórico em que se enredava:

E por isso o artista consegue essa transfiguração que será porventura o maior destino da arte: dentro da beleza objetiva da técnica, dentro de uma verdade plástica da melhor qualidade, como que o desaparecimento mesmo de todo este valor estético que se põe humildemente ao serviço de um sentimento ideal. A perfeição técnica da obra deixa de existir, não porque não exista, mas porque jamais existe por si mesma. Ela deixa de existir porque é da sua mais exata missão jamais ser "estética", jamais ser hedonística, desaconselhadamente livre em sua beleza, mas ser de fato "artística", nos preservando no mundo da própria vida com suas dores fidelíssimas. ${ }^{21}$

Diante do impasse, Mário costuma tomar o partido da política contra a estética, sua consciência militante superando sua "sensibilidade aristocrática", como ele dizia ${ }^{22}$. A renúncia implicada na escolha, entretanto, não era pequena, uma vez que Mário possuía uma sensibilidade estética refinada e exigente. A oposição entre os valores estéticos e políticos da obra de arte era portanto dramática para ele. Na conhecida conferência sobre o movimento modernista, a separação entre beleza artística e função social da arte é pensada no contexto de uma reflexão dolorosa sobre a contradição irresolúvel, que dilacera a atividade intelectual de Mário, entre estética e política - contradição que se fundamenta, como se verá, noutra, entre indivíduo e sociedade:

Deformei, ninguém não imagina o quanto, a minha obra - o que não quer dizer que si não o fizesse, ela seria milhor... Abandonei,

21 ANDRADE, Mário de. Lasar Segall [1943]. In: Aspectos das artes plásticas no Brasil. Belo Horizonte: Itatiaia, 1984. p. 61.

22 Nessa linha, diz o Janjão d'O banquete: "Pela arte, pelo cultivo do espírito e refinamento gradativo, eu me aristocratizei cem por cento. Moral, intelectualmente, é incontestável que eu sou um aristocrata”. ANDRADE, Mário de. O banquete, op. cit., p. 63. 
traição consciente, a ficção, em favor de um homem-de-estudo que fundamentalmente não sou. Mas é que eu decidira impregnar tudo quanto fazia de um valor utilitário, um valor prático da vida, que fosse alguma coisa mais terrena que ficção, prazer estético, a beleza divina. ${ }^{23}$

A antinomia entre estética e política leva o pensamento de Mário de Andrade a um beco sem saída: a arte tem de ser um fato social, mas seu elemento específico - o elemento estético - afasta a obra de arte da sociedade; ou, dizendo de outro modo: a produção de arte engajada, que as injustiças sociais exigem de todo artista, supõe o sacrifício da própria arte - o que levaria o artista, em última instância, a deixar de ser artista, a tornar-se "o homem-de-estudo que fundamentalmente não é" ${ }^{24}$.

Nesse quadro, a oposição entre qualidade estética e função social da produção artística cinde o próprio conceito marioandradino de arte. As reflexões de Mário nesse campo oscilam entre duas concepções extremas e contrárias: ora a arte é entendida por ele como a forma por excelência de afastamento do mundo, ora como poderoso meio de participação nos conflitos sociais. Assim, por um lado, não raro o "desinteresse", ou seja, a ausência de finalidade prática, figura no pensamento de Mário como o atributo essencial da arte:

Se a gente generaliza a Arte pra chegar a um conceito essencial dela, a noção de Desinteresse avulta e se torna mesmo o elemento primordial da criação artística. ${ }^{25}$

23 ANDRADE, Mário de. O Movimento Modernista [1942]. In: Aspectos da literatura brasileira, op. cit., p. 279.

24. Sacrifício, este, muito maior do que a renúncia à qualidade estética da obra de arte: "Quando falei que houve um sacrifício de mim, e há, no que faço, creio que não me referi ao sacrifício da linguagem que embora exista, tenha existido principalmente nos primeiros tempos, não tem a mínima importância pra ninguém, nem pra mim. O sacrifício penoso é o das minhas liberdades morais cerceadas; o mais penoso ainda é o das minhas verdades intelectuais, independentes até de mim, e por mim mesmo rejeitadas no que escrevo e ajo, em proveito da normalização, da fixação, da permanência de outras verdades humanas, sociais que eu friamente sei que são mais importantes". Carta de Mário de Andrade a Manuel Bandeira, 16 de agosto de 1931. MORAES, Marcos Antonio de (org.). Correspondência: Mário de Andrade \& Manuel Bandeira. São Paulo: Edusp/IEB, 2000. p. $5^{20}$.

25 ANDRADE, Mário de. Desinteresse. In: . Táxi e crônicas no Diário Nacional, op. cit., p. 95 . 
A Arte se caracteriza, entre as manifestações humanas, justamente por ser uma libertação da vida prática, isto é, por ser imediatamente desnecessária. ${ }^{26}$

Por outro lado, em passagens não menos numerosas e importantes, Mário define a arte em sentido oposto, como práxis social. No "Movimento Modernista", retoma a dissociação entre estética e política, situando o artístico no campo da segunda: "A liberdade da pesquisa estética lida com formas, com a técnica e as representações da beleza, ao passo que a arte é muito mais larga e complexa que isso, e tem uma funcionalidade imediata social, é uma profissão e uma força interessada da vida" 27 .

A perspectiva inverteu-se e a quididade da arte, agora, é o "interesse", a função prática, de natureza política, da criação artística - mas ao preço da exclusão do belo, como se verá adiante. Em vez de um fenômeno que liberta e distancia do real, a arte aparece aqui, justamente, como um meio pelo qual o homem adere à sociedade: "Arte é uma forma de contato, é uma forma de crítica, é uma forma de correção. É uma forma de aproximação social" "28. Levando a ideia às suas últimas consequências, Mário refere-se ao caráter essencialmente político da obra de arte como a algo da ordem da objetividade, portanto inescapável e independente do artista: "Mesmo a obra-de-arte mais livre, mais 'hedonística', é sempre um fator social, um elemento funcional" ${ }^{29}$; "O artista pode não ser político enquanto homem, mas a obra de arte é sempre política enquanto ensinamento e lição; e quando não serve a uma ideologia serve a outra, quando não serve a um partido serve ao seu contrário" ${ }^{\text {. }}$.

O momento que condensa e melhor ilustra o desnorteante vaivém teórico do pensamento estético de Mário, em particular no que se refere ao caráter contraditório das reflexões do escritor sobre o conceito mesmo de arte, encontra-se na Introdução à estética musical. Obra didática, organizada com base em cursos ministrados pelo escritor nas décadas de 1920 e 1930, na qual Mário procura sistematizar suas reflexões sobre a arte em geral e a música em particular ${ }^{31}$. O terceiro capítulo do livro, "Da Arte", inicia-se com uma fórmula: "Definição: Arte é a expressão livre e sem interesse imediato do ser racional". Partindo dessa proposição,

26 Idem. Pequena história da música. Belo Horizonte: Itatiaia, 1987. p. 114.

27 Idem. O Movimento Modernista, op. cit., p. 276.

28 Idem. Distanciamentos e aproximações, op. cit., p. 354 .

29 Idem. O banquete, op. cit., p. 130.

zo Acusa Mário de Andrade: “Todos são responsáveis!”, op. cit., p. 108.

31 ANDRADE, Mário de. Introdução à estética musical. São Paulo: Hucitec, 1995. p. $21-32$. 
Mário, inicialmente, analisa o conceito de arte em perspectiva histórica. Resumindo o argumento, a beleza e o prazer estético, segundo o escritor, estão na origem da arte, cuja primeira expressão teria sido a decoração primitiva de utensílios, por meio da qual "ao objeto prático de uso diário o primitivo ajunta um elemento novo desnecessário que lhe vai tornar o utensílio além de útil agradável”. Aos poucos, o homem passa a atribuir à arte uma finalidade prática, exterior, integrando a representação artística aos ritos mágico-religiosos, associação que perdura até o fim da Antiguidade, quando a arte volta a tornar-se livre de qualquer utilidade. Esse processo de autonomização, de emergência da "arte-pura", acelerase a partir da Renascença e se completa na modernidade: "A Arte em seu conceito evoluído se tornou expressão livre e desprática do espírito idealizando a vida".

Concluída a exposição histórica do conceito, Mário passa a discorrer sobre "a necessidade da arte". À medida que o texto avança, entretanto, o conceito de arte formulado ao final da seção anterior é relativizado sob diversos ângulos ("a gente não deve pois dizer que a arte é desnecessária a não ser que se dê a esta palavra um sentido muito particular"), por meandros que não cabe reproduzir por completo aqui, ao ponto de sofrer uma inversão completa. Primeiro, a representação artística passa a ser vista também como um meio de conhecimento, não apenas de prazer: "Arte é a expressão que nos dá o conhecimento virtual da vida. [...] A expressão dum interesse vital foi sempre a finalidade de todas as obras-primas". Em seguida, Mário procede a uma “dissociação das ideias do Belo e da Arte", contrariando frontalmente observações que fizera três páginas antes: "O Belo tem de ser dissociado da ideia de Arte pra que esta seja compreendida. [...] Se a gente observa qualquer obra-prima percebe logo o que eu afirmo" ${ }^{2}$. A separação entre a beleza e o artístico (o que não impede, naturalmente, que Mário reconheça que uma obra de arte possa eventualmente ser útil e bela, mas significa que esses dois elementos, o estético e o político, são distintos) leva o escritor a criticar a pobreza "do que se chama Arte-pura” e a formular, por fim, um novo conceito de arte, contrário ao anterior, em que a arte é vista como forma interessada da vida: "A expressão dum interesse vital foi sempre a finalidade de todas as obras-primas. [...] A dissociação [entre as ideias

32 Logo antes, porém, num momento em que esboça uma síntese entre o estético e político, Mário afirmara o oposto: "Nas expressões de Arte mais universalmente aceitas como supremas, na obra de um Ésquilo, dum Shakespeare, dum Miguel Anjo, dum Cervantes, dum Rembrandt, dum Beethoven, dum Whitman a Arte apresenta sempre uma ideia, um ideal mais interessados e práticos a que a ideia do Belo se associa”. 
do belo e da arte] nos permite verificar que antes de mais nada a Arte é expressão e conhecimento". Sobre o movimento surpreendentemente contraditório desse texto, Mário fez um comentário revelador, em carta de 1944 a Moacir Werneck de Castro:

Vou conceituando a arte, conceituando, quando chego no conceito da "liberdade" e independência total da arte, de repente dou um salto mortal, uma guinada que ninguém espera (nem eu esperava, relendo a coisa agora!) e termino a conferência concluindo que a arte é interessada. ${ }^{33}$

Sem conseguir dialetizar os campos da estética e da política, mas ao mesmo tempo, exigindo exasperadamente a realização dessa dialética, o pensamento marioandradino oscila, portanto, de forma constante e vertiginosa - para o próprio autor, ainda mais para o crítico - entre opostos irredutíveis.

Nesse ponto, para que avance a compreensão das ideias de Mário sobre a arte, deve-se perguntar: por que ele não conseguiu articular teoricamente liberdade artística e engajamento social? Por que, apesar dos esforços desmedidos que realizou, não pôde superar a antinomia entre estética e política? Mário possuía uma inteligência extraordinária, uma erudição notória, uma profunda experiência das coisas brasileiras, um talento literário multifacetado e uma disposição inigualável, entre os escritores nacionais, para dar uma função social à cultura no Brasil. As causas principais do relativo "fracasso" teórico de Mário, portanto, são menos subjetivas que objetivas. Elas se encontram sobretudo na história, isto é, no movimento e nas estruturas da sociedade brasileira

33 Carta de Mário de Andrade a Moacir Werneck de Castro, 23 de fevereiro de 1944. In: CASTRO, Moacir Werneck de. Mário de Andrade: exílio no Rio. Rio de Janeiro: Rocco, 1989. p. 216 (grifo meu). A noção de "salto mortal”, usada por Mário para definir a passagem do conceito de arte pura para o conceito de arte engajada, é significativa. O sacrifício será a mediação extrema que permitirá ao escritor realizar a passagem tão necessária quanto impossível, no quadro conceitual de Mário -, do estético para o político, pois o sacrifício constitui, no pensamento marioandradino, a mediação de uma relação ainda mais importante, a relação entre indivíduo e sociedade. Assim, n'O banquete, Janjão, o artista, utiliza a mesma imagem do salto mortal para caracterizar sua decisão pelo engajamento político: "Meu Deus! Meu Deus! que atitude tomar diante das formas novas, coletivas e socialistas da vida que encerram pra mim quase todas as vozes verdadeiras do tempo e do futuro? Mas vozes 'coletivas' que não interessam ao meu individualismo nem podem me fazer feliz ou desinfeliz? Mas de que tenho de participar, porque a isso me obriga a minha própria satisfação moral de indivíduo? [...] Pra mim as formas do futuro serão sempre um me atirar no abismo...". ANDRADE, Mário de. O banquete, op. cit., p. 63,65 (grifo meu). 
da primeira metade do século XX, em particular em São Paulo, entre os anos 1920 e 1945 .

Como se sabe, trata-se do período em que se opera uma importante mudança no Brasil: a transição da economia agrário-exportadora para a estrutura produtiva urbano-industrial. Justamente com o desenvolvimento da indústria, constitui-se um proletariado no país e um incipiente movimento operário começa a organizar-se, principalmente nas capitais paulista e federal ${ }^{54}$. Sua força crescente, a partir de 1900 , manifesta-se em greves cada vez mais frequentes e abrangentes contra as péssimas condições de trabalho nas fábricas, processo que culmina nas grandes greves de 1917 e 1919, que paralisaram as atividades industriais não apenas da cidade, mas também do Estado de São Paulo ${ }^{35}$. Os operários paulistas, em síntese, ameaçam constituir-se como classe revolucionária: "1917 inaugura a fase revolucionária das greves: até 1919, elas atingem intensidade e um grau tático nunca alcançados. O operariado toma consciência de que pode açambarcar o poder"36.

As possibilidades políticas efetivas do proletariado, entretanto, eram bastante reduzidas. Embora tivesse alcançado um nível de organização capaz de interromper os fluxos de produção e comércio de uma cidade como São Paulo, o movimento operário, considerado em relação à força repressiva das classes dominantes, ainda era frágil. A repressão brutal impedia a formação de lideranças estáveis, o adensamento da organização além dos limites municipais e a ampliação da representatividade dos partidos operários, de modo que não se constituía, no movimento dos trabalhadores, um programa unificado de curto e longo prazos, em escala nacional, voltado para a tomada do Estado. A partir da greve de 1917, quando o alarme soa para as elites de São Paulo, a repressão do movimento operário, antes intermitente, embora sempre violenta, adquire um caráter sistemático, desdobrando-se em um processo propriamente repressivo, com base na aliança efetiva dos industriais com a polícia ${ }^{37}$, e em um processo regulatório, fundado na ação do Estado, que culminaria na legislação trabalhista de Vargas e

34. Ver CARONE, Edgard. Movimento operário no Brasil (I877-1944). São Paulo: Difel, 1984. Ver também HALL, Michael; PINHEIRO, Paulo Sérgio. A classe operária no Brasil, 1889-1930. São Paulo: Alfa-Ômega/Brasiliense, 1979; e BATALHA, Cláudio. O movimento operário na Primeira República. Rio de Janeiro: Jorge Zahar, 2000.

35 Ver BEIGUELMAN, Paula. A formação do povo no complexo cafeeiro: aspectos políticos. São Paulo: Pioneira, 1978. p. 190-200.

36 CARONE, Edgard. República Velha (instituições e classes sociais). São Paulo: Difusão Europeia do Livro, 1970.

37 DEAN, Warren. A industrialização de São Paulo (1880-1945). São Paulo: Difel, s.d., p. 174-180. 
na criação de uma estrutura sindical corporativa e oficialista, que transferia o controle dos sindicatos ao governo ${ }^{38}$. Em poucos anos, o movimento dos trabalhadores, que começava a esboçar-se como força autônoma e unificada, foi desarticulado pelas classes dirigentes do país, que não encontraram grandes dificuldades para desmanchar uma estrutura que não ultrapassara os rudimentos de seu processo de formação. O êxito da empresa repressiva foi grande e rápido: em 1919, o meeting de $1^{\circ}$ de maio reunira por volta de sessenta mil pessoas na Praça Mauá, no Rio de Janeiro; em 1929, apenas vinte mil ${ }^{39}$. A nascente organização proletária brasileira dissolveu-se: “No momento de refluxo, os líderes do movimento operário [...] não sabiam como dirigir um recuo organizado da massa em face da onda de repressão que se desencadeava"40.

O processo de repressão e controle dos movimentos populares, associado à emergência de ideologias reacionárias e autoritárias - em particular o Integralismo de Plínio Salgado - entre as classes dirigentes do país, culmina no golpe de Estado de Vargas e na instalação do Estado Novo. Como se sabe, Vargas mobilizou uma perseguição feroz contra os comunistas, pôs fim à autonomia de organização do proletariado por meio da subordinação dos sindicatos ao Estado e regulamentou as relações de trabalho, aparentemente promovendo os direitos trabalhistas, mas em verdade legalizando condições degradadas de trabalho. Dessa forma, ou seja, por meio de uma política em que a violência era o elemento principal

38 “Um dos objetivos primordiais da 'nova política' na área trabalhista era impedir a organização autônoma da classe operária. O sindicato oficial, apesar do breve retorno ao pluralismo no interregno de 1934-1937, serviu para desmantelar toda a possibilidade de organização efetiva da classe operária e para controlá-la." PINHEIRO, Sérgio Paulo. Trabalho industrial no Brasil: uma revisão. Novos Estudos CEBRAP, São Paulo, n. 14, p. 119-131, 1975. Ver também ALENCASTRO, Luiz Felipe de. A pré-revolução de zo. Novos Estudos CEBRAP, São Paulo n. 18, p. 17-21, 1987; e MORAES FILHO, Evaristo de. O problema do sindicato único no Brasil: seus fundamentos sociológicos. São Paulo: Alfa-Ômega, 1978.

39 PINHEIRO, Sérgio Paulo. O proletariado industrial na Primeira República. In: FAUSTO, Boris (org.). História geral da civilização brasileira, tomo III: o Brasil Republicano. Rio de Janeiro: Bertrand Brasil, 1997, v. 2. p. 135-178. Vale notar que Mário de Andrade abordou esse processo histórico de repressão do movimento dos trabalhadores no conto "Primeiro de Maio", escrito entre 1934, e 1942. O texto narra a decepcionante experiência de um trabalhador que sai às ruas de São Paulo para comemorar o Dia do Trabalho, mas que ao invés de encontrar uma festa proletária, encontra uma cidade quase deserta, ocupada pela polícia, e uma celebração oficial no Palácio da Indústrias, presidida pelo patronato e pelo governo. ANDRADE, Mário de. Primeiro de Maio. In: Contos novos. Belo Horizonte: Itatiaia, 1999. p. $35-42$.

40 KONDER, Leandro. A derrota da dialética: a recepção das ideias de Marx no Brasil, até o começo dos anos zo. São Paulo: Expressão Popular, 2009. p. 160. 
de organização das estruturas econômicas e sociais do país, o governo de Vargas criou as condições práticas, ideológicas e institucionais para o desenvolvimento da acumulação primitiva do capitalismo industrial no Brasil ${ }^{41}$. Em síntese: uma variação local do fascismo tomou o poder político na sociedade brasileira. Apesar de assumir os mais variados nomes, aspectos e formas, o que por vezes levou à tese de que é um fenômeno indefinível, o fascismo se distingue por alguns traços essenciais, como a repressão do movimento sindical independente, o bonapartismo, a oposição violenta ao comunismo, o apoio da classe média, a sedução de parte do operariado e a acumulação forçada e monopolista de capital industrial ${ }^{42}$. Esses processos, que se condicionam reciprocamente, caracterizam a dinâmica e a estrutura da sociedade brasileira dos anos 1930 e $1940^{43}$.

No Brasil, portanto, a emergência do capitalismo industrial, mediada pelo modelo desenvolvimentista e de inclinação fascista implantado por Vargas, significou a dissolução de uma nascente luta de classes. A formação de um movimento operário consciente e organizado constituía fenômeno recente na sociedade brasileira, onde o regime de trabalho se baseara na escravidão até o final do século XIX. Esse movimento, por meio do qual começara a emergir, contra a brutal exploração multissecular do trabalho no Brasil, um novo sujeito histórico, foi todavia sufocado em seus inícios, o que bloqueou o desenvolvimento da luta de classes no país.

As contradições socioeconômicas, por sua vez, agravaram-se. A transição da economia primário-exportadora para a economia urbano-industrial não implicou a ruptura antigo sistema; ao contrário, realizou-se por meio da preservação de formas primitivas de acumulação capitalista e da renovação de relações arcaicas de produção. A articulação entre estruturas socioeconômicas "modernas" e "atrasadas" impulsionou um processo de modernização conservadora que aumentou a distância entre

41 Sobre a relação entre a legislação trabalhista brasileira consolidada no governo Vargas e o processo de acumulação primitiva do capitalismo industrial brasileiro, ver OLIVEIRA, Francisco de. Crítica à razão dualista/O ornitorrinco. São Paulo: Boitempo, 2003. p. 29-69.

42 Nessa linha, ver a reunião de textos clássicos sobre o fascismo que se encontra em BEETHAM, David (org.). Marxists in the face of fascism. Manchester: University of Manchester Press, 1983.

43 Para uma discussão sobre o caráter fascista do Estado Novo, ver TAVARES, José Nilo. Getúlio Vargas e o Estado Novo. In: CASTRO, José Luiz Werneck de (org.). $O$ feixe e o prisma: uma revisão do Estado Novo. Rio de Janeiro: Jorge Zahar, 1991, v. 1. p. 73-81; e GOMES, Ângela Maria de Castro. O redescobrimento do Brasil. In: GOMES, Ângela Maria de Castro; OLIVEIRA, Lucia Lippi; VELLOSO, Mônica Pimenta. Estado Novo: ideologia e poder. Rio de Janeiro: Zahar, 1982. p. 109-15o. Sobre a natureza fascista do Integralismo, ver CHASIN, José. O integralismo de Plínio Salgado. São Paulo: Ciências Humanas, 1978. 
os rendimentos do capital e do trabalho; promoveu, portanto, um enorme crescimento da produtividade industrial por meio da ampliação da concentração de renda e poder. Nas relações de trabalho, a exploração atroz persistia tanto no setor rural, que a legislação trabalhista praticamente não alcançava, como no setor urbano, inchado pela formação de um "exército de reserva" constituído pelo contingente populacional que afluía do campo para a cidade ${ }^{44}$.

Tudo, em suma, pedia uma revolução no Brasil, mas nada tornava possível a projeção de sua efetiva realização. Essa contradição histórica está na base das oscilações e paradoxos do pensamento estético de Mário de Andrade $^{45}$. Noutras palavras, Mário não conseguiu encontrar na sociedade brasileira a mediação histórica que lhe permitiria articular dialeticamente o artístico e o político: a luta de classes. Sem poder chegar a conceber a luta de classes como categoria poética, não conseguiu formular uma ideia materialista de beleza, em que o movimento político se precipita no movimento artístico e a radicalidade política assume a forma da radicalidade estética ${ }^{46}$. Por outro lado, a urgência de uma revolução na sociedade brasileira tornava irrenunciável, para um intelectual verdadeiro como Mário, a exigência de que a arte assumisse um caráter politicamente engajado. Situado em um contexto histórico em que se combinam a rarefação da luta de classes e a urgência de revolução, o escritor se vê em uma posição paradoxal, na medida em que não pode produzir, mas tem de produzir, uma arte militante.

A consciência de que a contradição entre o estético e o político contradição que é, para Mário de Andrade, a forma por excelência da contradição entre indivíduo e sociedade - ao mesmo tempo deve e não tem como ser resolvida provoca nas reflexões teóricas e na produção literária do escritor um acirramento vertiginoso dessa antinomia. Com efeito, Mário e sua obra não se furtam à intensificação desse conflito; ao contrário, como observou Lafetá, “Mário se colocou, o tempo todo, no centro da contradição,

44. OLIVEIRA, Francisco de. Crítica à razão dualista/O ornitorrinco, op. cit., p. 29-69. FERNANDES, Florestan. A revolução burguesa no Brasil. São Paulo: Globo, 2006. Sobre o sentido conservador da Revolução de 1930, ver ainda FAUSTO, Boris. ARevolução de 193o: historiografia e história. São Paulo: Brasiliense, 1976.

45 Assim, vinculadas à precariedade de nossa formação social, as oscilações e paradoxos do pensamento estético de Mário de Andrade pertencem à extensa linhagem de dualidades de toda sorte que marcam a experiência intelectual brasileira. Ver ARANTES, Paulo Eduardo. Sentimento da dialética na experiência intelectual brasileira. São Paulo: Paz e Terra, 1992.

46 Isso não quer dizer que Mário não tenha realizado essa conjunção em sua obra, mas que não conseguiu formulá-la teoricamente. 
e terminou por fazer dela o fulcro de suas reflexões literárias" ${ }^{\text {47 }}$. Assumindo-a plenamente - fisicamente inclusive, ou seja, no próprio corpo -, procura levá-la às suas últimas consequências para, quem sabe dessa forma, resolvê-la. A exasperação do antagonismo entre o estético e o político leva o escritor a formulações desesperadas, como a de que a poesia, para ser socialmente verdadeira, deve mentir a si mesma: "Ou a Poesia se traia inteiramente e vire cantadora pragmática dos interesses sociais, ou vire, no máximo orgulho, inexoravelmente senhoril" ${ }^{48}$; ou como a de que a verdade do sujeito implica a mentira social e a verdade social, a mentira do sujeito: "Ou o compositor faz música nacional e falsifica ou abandona a força expressiva que possui, ou aceita esta e abandona a característica nacional" ${ }^{49}$. Nesse contexto, ou seja, no momento paroxístico em que os antagonismos que dividem o pensamento estético de Mário de Andrade se organizam na forma de uma oposição absoluta - portanto no momento em que a experiência das contradições sociais brasileiras alcança a sua máxima violência, uma vez que os impasses teóricos formulados pelo escritor se vinculam, conforme dito, a impasses históricos - Mário recorrerá à mediação extrema pela qual se podem articular o indivíduo e a sociedade, o sacrifício.

A solução sacrificial, que se impõe no instante em que o embate do escritor militante com a matéria histórica brasileira alcança a sua exasperação máxima, prende-se ainda à própria formação intelectual de Mário de Andrade. Em seu estudo clássico sobre a "estrutura ideológica" do autor de Macunaíma, Telê Porto Ancona Lopez demonstra que a evolução das ideias de Mário sobre a cultura se desenvolve em torno de dois eixos teóricos fundamentais, o catolicismo e o marxismo, que não apenas coexistem, mas se articulam intimamente desde as primeiras reflexões do escritor acerca da situação social da $\operatorname{arte}^{50}$. Assim, a exigência de engajamento na história se associa, no pensamento marioandradino, a certo ideal cristão de fraternidade e, no limite, ao modelo da Imitatio Christi $^{51}$. A participação da arte nas questões sociais assumirá, nesse contexto, a forma de uma participation mystique, por meio da qual o sujeito adere ao processo histórico com todo o seu ser, isto é, não apenas

47 LAFETÁ, João Luiz. I93o: a crítica e o Modernismo, op. cit., p. 211.

48 ANDRADE, Mário de. A poesia em 1930, op. cit., p. $5^{2}$.

49 Idem. Ensaio sobre a música brasileira. Belo Horizonte: Itatiaia, 2006. p. $3^{1}$.

$5^{\circ}$ LOPEZ, Telê Porto Ancona. Mário de Andrade: ramais e caminho. São Paulo: Duas Cidades, 1972. p. 21-71.

51 Em agosto de 1913, conforme observa Marcos Antonio de Moraes, Mário de Andrade recebeu de seu irmão Carlos, e leu com atenção, o volume da Imitação de Jesus Cristo de Thomas de Kempis. Ver MORAES, Marcos Antônio (org.), op. cit., p. 379. 
com a razão, mas com a emoção, a sensibilidade e o próprio corpo: "Eu estuo e quebro-me de amor. Por todos os homens", escreve Mário, em termos que fazem pensar na tradição do misticismo cristão, a Manuel Bandeira, em carta de $1923^{52}$.

Além da formação ideológica, também a formação artística de Mário de Andrade contribuía para que o escritor concebesse a militância política do artista sob a forma do sacrifício. Em carta de agosto de 1944 a Guilherme Figueiredo, Mário revela que lhe é "dificílimo”, "por educação e tradição pessoal”, escrever artigos de "assuntos participantes"; nascido na última década do Oitocentos, nutrira-se do fin de siècle, ou seja, de uma cultura burguesa, estetizante e decadente:

Para nós, pros da nossa geração vinda dos 800, [...] nos é por assim dizer impossível obter qualquer espécie de... de espontaneidade, meu Deus!, de solidariedade humana em estado poético, em estado de escritura!... Não é que não tenhamos essa solidariedade

52 Idem, ibidem, p. 99. A presença do modelo crístico na representação do engajamento sociopolítico atravessa a obra literária de Mário de Andrade do princípio ao fim. No livro de estreia do autor, o conjunto de poemas pacifistas Há uma gota de sangue em cada poema (1917), esse modelo permeia todo o livro, das imagens à estrutura, dos temas à linguagem, condensando-se no verso de "Guilherme": "[Ser grande] é ser bom finalmente, é ser Jesus!...". Na famosa "Ode ao burguês", de Pauliceia desvairada (1922), Mário assume, como notou Telê Ancona Lopez, uma "posição semelhante à de Cristo vergastando os vendilhões do templo", dedicando ao burguês um “ódio vermelho", possível alusão à Revolução Russa. Em Macunaíma (1928), livro em que não há propriamente engajamento político, mas que é a grande síntese do engajamento ainda apenas cultural a que Mário se dedicou ao longo dos anos 1920, o retorno do herói para o Uraricoera no final da rapsódia, segundo me sugeriu certa vez a professora Maria Augusta Fonseca, assemelha-se a uma via crucis. O modelo da via crucis, ainda, foi percebido por Iná Camargo Costa no conto mais político de Mário, o "Primeiro de Maio" (1934 - 1942), no qual cada estação do périplo do operário 35 por São Paulo corresponde a uma etapa de um doloroso processo de tomada de consciência de classe. Por fim, conforme nota Sérgio de Carvalho, no centro da última cena do Café (1933 - 1942), a cena da revolução popular, um líder revolucionário morre nos braços da esposa no meio do palco, o conjunto figurando uma Pietà, em torno da qual turbilhona a revolta social. O paradigma do Cristo sacrificado opera, ainda, em outras obras de Mário, de modo mais discreto ou indireto, em especial por meio de uma estrutura mágico-religiosa ainda mais inclusiva, a dos ritos de vegetação, que Mário conheceu na obra de Frazer e incorporou profundamente em seu pensamento sociocultural e em sua literatura. Ver LOPEZ, Telê Porto Ancona, Mário de Andrade: ramais e caminho, op. cit., p. 4o. COSTA, Iná Camargo. Mário de Andrade e o Primeiro de Maio de 35, Trans/ Form/Ação: Revista de Filosofia, São Paulo, v. 18, p. 37-41, 1995. Por fim, CARVALHO, Sérgio Ricardo de. O drama impossível: teatro modernista de António de Alcântara Machado, Oswald de Andrade e Mário de Andrade. 2003. 226 f. Tese (Doutorado em Literatura Brasileira) -Faculdade de Filosofia, Letras e Ciências Humanas, Universidade de São Paulo, 2003. p. 175-200. 
humana, mas pelo vício da educação artística que tivemos, e também pelo total desfibramento moral do fim do século, que foi o leite em que bebemos, essa solidariedade não consegue se transfundir por si mesma, por espontaneidade dela em poesia, em prosa de ficção, em artigo de inteligência lógica. ${ }^{53}$

Como se terá notado, Mário não se refere apenas a si mesmo, mas também a seus pares, os modernistas. Dois anos antes, fizera justamente a crítica do Movimento Modernista brasileiro, que apesar do vanguardismo agressivo preservara, segundo o escritor, o "caráter aristocrático" e abstencionista da cultura tradicional, e vinculara seu espírito e sua atividade à "nobreza regional", a burguesia cafeeira paulista ${ }^{54}$. Ainda que não pertencesse, ao contrário das principais figuras do movimento, às elites rurais da civilização do café, mas à pequena ou média burguesia da cidade de São Paulo, Mário pensava a si mesmo como a um "aristocrata" de espírito ${ }^{55}$. Nesse quadro, conforme dito, o engajamento político do artista implica um sacrifício ainda mais doloroso que o sacrifício da qualidade estética de sua obra:

Quando falei que houve um sacrifício de mim, e há, no que faço, creio que não me referi ao sacrifício da linguagem [...]. O sacrifício penoso é o das minhas liberdades morais cerceadas; o mais penoso ainda é o das minhas verdades intelectuais, independentes até de mim, e por mim mesmo rejeitadas no que escrevo e ajo, em proveito da normalização, da fixação, da permanência de outras verdades humanas, sociais que eu friamente sei que são mais importantes. ${ }^{56}$

53 ANDRADE, Mário de. A lição do guru (cartas a Guilherme Figueiredo (1937-1945)), op. cit., p. 103.

54 Idem. O Movimento Modernista, op. cit., p. 259-280.

55 Assim, n'O banquete, quando o Pastor Fido sugere que Janjão faça "arte de combate que alcance o povo", o compositor responde, falando por Mário de Andrade: “Não creio, infelizmente, que seja esse o meu papel de artista erudito. Pelo menos enquanto o povo for folclórico, como falei. Seria me adaptar falsamente a sentimentos e tendèncias que não poderão nunca ser os meus. Eu sou de formação burguesa cem por cento, você esquece? E pela arte, pelo cultivo do espírito e refinamento gradativo, eu me aristocratizei cem por cento. Moral, intelectualmente, é incontestável que eu sou um aristocrata". No mesmo sentido, na conferência sobre o Movimento Modernista, Mário afirma que seu "aristocratismo" o impediu de realizar, apesar de sua dedicação ao desenvolvimento da função social da arte no Brasil, uma obra engajada. Idem. O banquete, op. cit., p. 63; O Movimento Modernista, op. cit., p. 277 .

56 Carta a Manuel Bandeira, 16 de agosto de 1931. MORAES, Marcos Antônio (org.), op. cit., p. 520. O problema da posição ideológica do intelectual de formação burguesa 
Na obra de Mário, é por meio do ato sacrificial que o indivíduo se torna a sociedade e a estética, a política. Mas o sacrifício, estrutura que deitas suas raízes no mito, constitui uma mediação ambivalente e contraditória, pois opera, justamente, com a identificação imediata. Segundo a lógica sacrificial, o particular é imediatamente o universal, a subjetividade é imediatamente a coletividade ${ }^{57}$. A passagem do indivíduo na

remonta às jornadas de junho de 1848 , quando "os fogos de artifício de Lamartine transformaram-se nas bombas incendiárias de Cavaignac", na conhecida frase de Marx - isto é, quando a burguesia se afirma como classe dominante e retira a máscara universalista de sua ideologia. Configurada e declarada a nova luta de classes, a proletarização do escritor moderno, de formação burguesa, "não [se dará] sem lutas amargas, não sem conflitos extremamente difíceis”, como disse Benjamin. O engajamento passa a implicar uma traição de classe, pois além de supor que o artista "mude de lado", presume que ele coloque sua formação intelectual a serviço da luta dos despossuídos. No Brasil, entretanto, o salto que era desafiado a dar o intelectual que pretendia engajar-se nas lutas sociais era particularmente vertiginoso, uma vez que o grau de exclusão civil e cultural dos pobres diferia pouco, nos anos 1920, daquele dos escravos da sociedade brasileira do final do século XIX, de modo que os trabalhadores constituíam, na sua maior parte, um lumpemproletariado. Assim, um abismo separava os homens letrados e as classes populares, e sobretudo faltava, conforme dito, uma luta de classes organizada, que pudesse realizar a mediação dessa passagem do intelectual para a esquerda. Nesse quadro, o artista é chamado a ser imediatamente o seu absolutamente outro, o que implica não a renúncia, a qual supõe a presença da mediação e o retorno do sujeito a si mesmo, mas o sacrifício, o trânsito imediato e ruinoso do sujeito no objeto. Para as citações de Marx e Benjamin, ver MARX, Karl. A luta de classes em França de 1848 a 1850. In:__. Obras escolhidas - I. Lisboa: Avante, 1982. p. 230. BENJAMIN, Walter, op. cit., p. 135 . O movimento de passagem ruinosa do mesmo no outro, sugerido logo há pouco, foi percebido, formulado e estudado nas obras centrais da literatura brasileira por José Antonio Pasta Jr., que demonstra a constância dessa estrutura tanto no romance como na formação social brasileira. Ver PASTA JR., José Antonio. Volubilidade e ideia fixa (o outro no romance brasileiro). Sinal de menos, São Paulo, n. 4, p. 13-25, 2010; idem, O romance do Rosa - temas do Grande Sertão e do Brasil. Novos Estudos CEBRAP, São Paulo, n. 55, p. 61-7o, nov. 1999.

57 Hubert e Mauss, autores da melhor teoria do sacrifício de que se dispõe, demonstram a natureza essencialmente paradoxal do sacrifício, que se constitui como um conjunto de mediações que tem no seu núcleo, entretanto, a imediação. Assim, o sacrificante, ou seja, o beneficiário do sacrifício, ao mesmo tempo que se diferencia da vítima, deve identificar-se com ela: "Não basta dizer que a vítima representa 0 sacrificante; confunde-se com ele. As duas personalidades se fusionam. A identificação torna-se tal [...] que o destino futuro da vítima, sua morte próxima, tèm uma espécie de efeito sobre o sacrificante". Por isso, de acordo com Hubert e Mauss, a forma mais acabada do sistema sacrificial seria a autoimolação do deus, em que a vítima e o carrasco são o mesmo. Embora em contexto teórico distinto, Lévi-Strauss observa, em sentido análogo, que o sacrifício opera por "continuidade", isto é, estabelece uma série de identificações sucessivas e imediatas entre as personagens do rito sacrificial. HUBERT, Henri; MAUSS, Marcel. Sobre o sacrifício. São Paulo: Cosac Naify, 2005. LÉVI-STRAUSS, Claude. O pensamento selvagem. Campinas: Papirus, 2007. p. 24,8-254. 
sociedade implica, portanto, a extinção do sujeito - o sacrifício distinguese de outras formas de oferenda na medida em que supõe a destruição da oferenda, a morte da vítima ${ }^{58}$. Por outro lado, na medida em que o indivíduo passa inteiramente, pois que imediatamente, na coletividade, esta se extingue no indivíduo: toda a sociedade morre simbolicamente na vítima, que por sua vez adquire, por meio de sua própria imolação, um caráter sagrado. No regime paradoxal do sacrifício, portanto, a negação abstrata do particular consiste ao mesmo tempo na negação abstrata do universal, isto é, na afirmação absoluta do particular ${ }^{59}$.

Não por acaso, na obra de Mário, a passagem da estética para a política por meio do sacrifício não resolve a contradição que o escritor identifica entre os dois campos. Uma das razões desse fracasso reside no fato de que a solução sacrificial conduz, no limite, não apenas ao sacrifício da qualidade estética da obra de arte, mas à morte do próprio artista e de sua arte. Sobre sua decisão - no momento em que se dilacerava, "na insolubilidade sufocante em que vivia" ${ }^{\text {, }}$, entre o desejo de escrever literatura e o dever moral de participar das lutas sociais - de aceitar o convite para dirigir o Departamento de Cultura de São Paulo, Mário escreveu a Murilo Miranda, revelando a dimensão propriamente sacrificial de seu gesto:

O Departamento vinha me tirar do impasse asfixiante. [...] Ia agir. Me embebedar de ações de iniciativas, de trabalhos objetivos, de luta pela cultura. Certamente não posso encarar isso como uma perfeição do meu ser interior. [...] Mas era sempre me conservar utilitário, dando uma pacificação às minhas exigências morais de escritor, pois tirava o escritor de foco, botando o foco no funcionário que surgia. Me suicidei sim. [...] Me lembro perfeitamente bem que disse também pra você que encarava isso como um

58 HERRENSCHMIDT, Olivier. A qui profite le crime? Cherchez le sacrifiant. L'homme. Revue française d'anthropologie, Paris, XVIII (1-2), p. 7-18, jan.-jun. 1978.

59 Hegel formulou o impasse: "O ser do finito é o ser do infinito. [...] Ora, é preciso notar que nessa proposição a mediação entre o ser do finito e o ser do infinito não aparece. Trata-se de uma proposição sem mediação, precisamente o contrário do que se demanda [para a obtenção de uma síntese religiosa superior]. O defeito dessa formulação está em que nela se exprime o finito como afirmativo". HEGEL, G. W. F. Leçons sur la philosophie de la religion, II, 1, Paris: Vrin, 1972, p. 46.

6o Carta de Mário de Andrade a Carlos Lacerda, 5 de abril de 1944, In: ANDRADE, Mário de. 7I cartas de Mário de Andrade. Rio de Janeiro: São José, s.d., p. 85. 
suicídio. [...] Percebi a possibilidade de um suicídio satisfatório e me suicidei. O Departamento é o meu túmulo. ${ }^{61}$

Mas além de promover a destruição do indivíduo na sociedade - no contexto do pensamento artístico marioandradino, a extinção do estético no político -, o sacrifício, conforme dito, concretiza também o movimento contrário, isto é, aniquila a sociedade no indivíduo. A partir dos anos 1930, Mário começou a perceber que ao sacrificar sua arte pela coletividade, sacrificava justamente a coletividade. Conforme Antonio Candido lembrou, um dos aspectos decisivos da personalidade de Mário era a solidariedade ${ }^{62}$, que se desdobrava em uma disposição para o sacrifício ${ }^{63}$. Preso à “dialética negativa” entre estética e política na qual se que enredava o seu trabalho, Mário dizia suportar, muitas vezes com prazer, a aniquilação de si mesmo em função da produção de um bem coletivo ${ }^{64}$. Era-lhe todavia trágica a consciência de que à medida que procurava dar à sua obra, por intermédio do sacrifício, um caráter coletivo - isto é, político -, mais individual - ou seja, estética - sua obra se tornava.

Mário identificou esse paradoxo em sua obra mais ambiciosa, $\mathrm{Macu}$ naíma, que ele classificava como "uma obra-prima ratada". Como se sabe, concebido como uma rapsódia, o livro "foi construído a partir da combinação de uma infinidade de textos preexistentes, elaborados pela tradição oral ou escrita, popular ou erudita, europeia ou brasileira" ${ }^{65}$, principalmente a tradição popular brasileira, constituindo-se por meio do agenciamento inventivo de uma quantidade gigantesca de fragmentos de materiais coletivos, de modo a formar uma espécie de grande síntese do Brasil:

61 Carta de Mário de Andrade a Murilo Miranda, 11 de novembro de 1936. ANDRADE, Mário de. Cartas a Murilo Miranda (1934-1945). Rio de Janeiro: Nova Fronteira, 1981. p. 39-41.

62 “Tinha o culto da solidariedade humana e só se entenderá a sua obra levando isso em conta”. CANDIDO, Antonio. Lembrança de Mário de Andrade. In: Brigada ligeira e outros ensaios, São Paulo: Editora Unesp, 1992. p. 210.

63 Ou, em outros termos, em uma "vocação sacrificial", como escreveram COLI, Jorge; DANTAS, Luiz. Sobre O banquete. In: ANDRADE, Mário de. O banquete, op. cit., p. 25.

64. "Nós temos que dar ao Brasil o que ele não tem e que por isso até agora não viveu, nós temos que dar uma alma ao Brasil e para isso todo sacrifício é grandioso, é sublime. E nos dá felicidade. Eu me sacrifiquei inteiramente e quando eu penso em mim nas horas de consciência, eu mal posso respirar, quase gemo na pletora da minha felicidade”. Carta de Mário de Andrade a Carlos Drummond de Andrade, 10 de novembro de 1924. ANDRADE, Carlos Drummond de. A lição do amigo: cartas de Mário de Andrade a Carlos Drummond de Andrade, op. cit., p. 6.

65 SOUZA, Gilda de Mello e. O tupi e o alaúde. São Paulo: Editora 34/Duas Cidades, 2003. p. 10. 
Minha intenção foi esta: aproveitar o máximo possível lendas tradições costumes frases feitas etc. brasileiros. E tudo debaixo dum caráter sempre lendário porém como lenda de índio e negro. O livro quase que não tem nenhum caso inventado por mim. [...] Misturei completamente o Brasil inteirinho. ${ }^{66}$

Nesse quadro, a própria autoria do livro se problematiza, Mário figurando como uma espécie de médium - ou melhor, na linguagem do candomblé, de "cavalo" - do povo brasileiro, que por sua vez fala através do escritor. Macunaíma, de fato, assim como outros livros de Mário, após longa preparação, teria sido escrito em um estado análogo ao transe de possessão - fenômeno essencialmente sacrificial ${ }^{67}$ - por meio do qual a cultura nacional teria se precipitado no livro:

[...] escrito em pleno estado de possessão (a primeira redação foi feita inteirinha em seis dias), em que eu não sofria nada no ímpeto sublime da criação, mas também nem podia pôr consciência na sublimidade em que estava pela extensão mesma desta sublimidade que me obnubilava qualquer estado de consciência analítica. ${ }^{68}$

66 Carta de Mário de Andrade a Luís da Câmara Cascudo, 10 de março de 1927. MELO, Veríssimo de (org.). Cartas de Mário de Andrade a Luís da Câmara Cascudo. Belo Horizonte/Rio de Janeiro: Villa Rica, 1991. p. 75-76.

67 "Entre as convulsões da vítima sacrificial nos transes de sua agonia e a agitação convulsiva do possuído, interpretadas como manifestações de uma presença e de uma possessão divinas, uma expressa analogia pode ser percebida”. JEANMAIRE, Henri. Dionysos: histoire du culte de Bacchus. Paris: Payot, 1991. p. 158. À medida que aumenta o interesse de Mário de Andrade pela cultura popular brasileira, a partir de meados da década de 1920, o transe de possessão dionisíaco, em cujo núcleo reside o sacrifício, tornou-se a forma privilegiada do processo criativo de Mário. O escritor encontrava desse modo uma estrutura sacrificial por meio da qual seu engajamento deitava raízes no folclore nacional. Para compor o Café, por exemplo, Mário buscou por muito tempo, em vão, a técnica, a forma e o tom que lhe permitiriam escrever uma ópera militante no Brasil, quando "de sopetão", recorda o escritor, em um mês de "entusiasmo" e "iluminações", toda a obra foi escrita: "foi sublime, vinha tudo fácil”. Nesse sentido, o processo de criação poética de Mário - e a criação em Mário, lembre-se, é sempre engajada - reproduz em certa medida o movimento do pensamento estético do escritor, aqui estudado. A composição das obras decisivas de Mário costuma ser precedida de uma longa preparação, de uma enorme acumulação de trabalho e pesquisa, por meio da qual Mário recolhe material, dialetiza hipóteses, testa soluções etc.; esse trabalho, entretanto, não se desenvolve como mediação principal da escrita, mas acumula contradições e se exaspera em paradoxos, "resolvendo-se" apenas em uma forma de transe, no qual "tudo" se precipita no papel.

68 ANDRADE, Mário de. Cartas a um jovem escritor e suas respostas (Fernando Sabino, Mário de Andrade). Rio de Janeiro: Record, 2ooz. p. $3^{2}$. 
No transe criador de Macunaima, o autor desaparece na coletividade, o que propicia, na obra de arte, a reunião de uma cultura que, no plano da história, ao contrário, encontra-se esparsa. Nesse sentido, o livro realizaria em grande escala o desejo de produzir uma literatura utilitária, que promovesse a integração da sociedade. Mário perceberia mais tarde, entretanto, que sua tentativa de produzir na rapsódia, por meio do sacrifício da dimensão autoral, uma "linguagem brasileira", em que se comunicassem as variedades linguísticas de todas as regiões e classes sociais do país, paradoxalmente resultara em uma linguagem estritamente pessoal: "Quis escrever um livro em todos os linguajares regionais do Brasil. O resultado foi que, como já disseram, me fiz incompreensível até para os brasileiros"69.

Na estética de Mário de Andrade, o sacrifício reinstaura, em grau ainda mais exasperante, a contradições entre indivíduo e sociedade, entre estética e política, contradições que o escritor, por intermédio do ato sacrificial, pretendia superar. Desse modo, o movimento das reflexões de Mário sobre a arte assume a forma de um círculo vicioso, em que o escritor se reconhece tanto mais preso quanto mais radicalmente procura dele escapar, enredando-se em paradoxos cada vez mais perturbadores. Na conferência sobre o Movimento Modernista, que tem algo de um testamento estético, Mário faz um balanço trágico de sua trajetória intelectual:

Não tenho a mínima reserva em afirmar que toda a minha obra representa uma dedicação feliz a problemas do meu tempo e minha terra. Ajudei coisas, maquinei coisas, muita coisa! E no entanto me sobra agora a sentença de que fiz muito pouco, porque todos os meus

69 Acusa Mário de Andrade: “Todos são responsáveis!”, op. cit., p. 105. Mário possivelmente se refere a Manuel Bandeira, que em 1931 lhe escrevera: "Sua nobre tentativa de linguagem brasileira, feita no pensamento de nos unir mais os brasileiros, ideia portanto altamente socializante, se tem afirmado dessocializante: a maioria das pessoas simples que leem você sentem dificuldade de compreendê-lo. Quando você escreve 'sube' e 'intaliano', ninguém sente o seu desejo de comunhão nem o seu sacrifício, mas a sua personalidade indiscreta e tirânica querendo impor na linguagem literária escrita formas da linguagem popular ou culta falada que agradam à sua sensibilidade de grande escritor". MORAES, Marcos Antonio de (org.), op. cit., p. 516. Roberto Schwarz faz uma observação semelhante: "Nada mais pessoal e intransferível que a fisionomia dessa escrita que se queria funcional, como que indicando que seu gigantismo não era repetível. Com efeito, hoje ela se lê como uma extraordinária façanha de expressão individual, associada ao desejo de aperfeiçoar a nacionalidade”. SCHWARZ, Roberto. Outra Capitu. In: Duas meninas. São Paulo: Companhia das Letras, 1997, p. 142. A coexistência de objetividade e subjetividade extremas em Macunaíma é identificada e interpretada por José Antonio Pasta Jr. em "Tristes estrelas da Ursa - Macunaima". PASTA JR., José Antonio. Tristes estrelas da Ursa - Macunaíma. Cadernos Porto \& Virgula, Porto Alegre, n. 4, p. 27-32, 1993 . 
feitos derivaram duma ilusão vasta. E eu que sempre me pensei, me senti mesmo, sadiamente banhado de amor humano, chego no declínio da vida à convicção de que faltou humanidade em mim. Meu aristocratismo me puniu. Minha intenções me enganaram.

Vítima do meu individualismo, procuro em vão nas minhas obras, e também nas de meus companheiros, uma paixão mais temporânea, uma dor mais viril da vida. Não tem. Tem mais é uma antiquada ausência de realidade em muitos de nós. Estou repisando o que já disse a um moço... E outra coisa senão o respeito que tenho pelo destino dos mais novos se fazendo, não me levaria a essa confissão bastante cruel, de perceber em quase toda a minha obra a insuficiência do abstencionismo. [...]

Eis que chego a esse paradoxo irrespirável: tendo deformado toda a minha obra por um anti-individualismo dirigido e voluntarioso, toda a minha obra não é mais que um hiperindividualismo. ${ }^{70}$

Desenvolvendo suas ideias em contexto de rarefação da luta de classes, Mário de Andrade não conseguiu superar de forma estável, em sua extensa e variada reflexão sobre a função social da arte, a contradição que se encontra na base de sua atividade intelectual, entre estética e política. Muitas vezes é a história, não o artista, quem fracassa na arte. Os impasses e paradoxos teóricos armados por Mário, entretanto, na medida em que dão forma a contradições históricas fundamentais, compõem um conjunto de momentos decisivos para a formação, no Brasil, de um pensamento que desenvolva as possibilidades da arte engajada no país e que supere a cisão, em que se dividiam as reflexões de Mário de Andrade, entre a estética e a política. Antes, porém, “alguém tinha que suportar todo o peso dessa cisão, travando no campo da própria consciência a batalha inevitável" 71 .

\section{Sobre o autor}

\section{Pedro Fragelli}

Pós-doutorando na Universidade de Paris III - Sorbonne Nouvelle (Paris, França). Mestre e doutor em Literatura Brasileira pela Universidade de São Paulo (2005 e 2011). E-mail: pedrofragelli@gmail.com

70 ANDRADE, Mário de. O Movimento Modernista, op. cit., p. 277-279.

71 ROSENFELD, Anatol. Mário e o cabotinismo. In: .Texto/Contexto I. São Paulo: Perspectiva, 1996. p. 192. 